\title{
COMPARING MOTIVATION AND PROFILE BETWEEN ARCHAEOTOURISTS AND NON- ARCHAEOTOURISTS IN NGORONGORO, TANZANIA
}

\author{
Noel Biseko LWOGA* \\ University of Dar es Salaam, Department of Archaeology and Heritage Studies, Tanzania, \\ University of Johannesburg, and School of Tourism and Hospitality, South Africa, e-mail: noelight79@gmail.com
}

Joshua MWANKUNDA

Ngorongoro Conservation Area Authority, Department of Cultural Heritage Management and Geoparks,

Arusha, Tanzania, e-mail: joshua.mwankunda@ncaa.go.tz

\begin{abstract}
Citation: Lwoga, N.B., \& Mwankunda, J. (2020). COMPARING MOTIVATION AND PROFILE BETWEEN ARCHAEOTOURISTS AND NONARCHAEOTOURISTS IN NGORONGORO, TANZANIA. GeoJournal of Tourism and Geosites, 32(4), 1394-1401. $\underline{\text { https://doi.org/10.30892/gtg.32430-586 }}$
\end{abstract}

\begin{abstract}
The study aims to compare motivation and profile between archaeotourists and non-archaeotourists. It utilizes the push and pull motivational model and distance decay theory, and questionnaire data from a sample of 252 international tourists visiting Ngorongoro Conservation Area (NCA) in Tanzania. The analysis revealed that archaeotourists are more heterogeneous than non-archaeotourists, as they not only attach importance to fascinating stories and the authenticity of past objects, but also to enjoying nature, the geological scenery, doing research on archaeological features and each other's company. In addition, they are older, have plenty of time to visit and are well off.
\end{abstract}

Key words: Ngorongoro, archaeotourism, archaeological site, tourist motivation, archaeotourist, Tanzania

$* * * * *$

\section{INTRODUCTION}

Tourism is one of the important sectors of economies that contributes to economic growth in the Sub-Saharan Africa (SSA) region (Rogerson and Rogerson, 2018; World Bank, 2019). Natural attractions, especially wildlife, beaches and a warm climate have been conventional factors pulling tourists to visit SSA (Lwoga, 2011). However, today, people's past and contemporary cultures are becoming more important in SSA's tourist product mix (Timothy and Nyaupane, 2009). Specifically, the archaeological sites evidencing the past of humankind are increasingly becoming one of the important attractions, thanks to the presence of famous sites such as Olduvai Gorge, the Cradle of Human Kind in Tanzania, and to the tourists' changing preferences. In fact, globally, tourists visiting archaeological sites - a phenomenon known as archaeological tourism or archaeotourism - is not a new phenomenon as people have long sought out archaeological sites around the world (Giraudo and Porter, 2010). Archaeotourism is being encouraged due to its potential to conserve and preserve the local heritage, educate the general populace about their heritage and revitalize places that have suffered from the effects of remoteness and abandonment (Odum and Oguamanam, 2020; Cahyadi, 2016). To mention just a few examples of archaeotourism promotion, the number of tourists visiting the Machu Picchu archaeological site grew rapidly, from 77,295 in 1991 to about 1.3 million in 2015 (OehmichenBazan, 2018). Archaeological sites in Guatemala are the reason for tourism being one of the main sources of income after the civil war ended in 1996 (Oehmichen-Bazan, 2018). In Egypt and in Europe, archaeotourism is among the mature tourist markets (Ercolano et al., 2018).

In Tanzania, archaeological sites came to the attention of international touristic and research expeditions since the colonial times. Archaeotourism gained further attention when the ruins of Kilwa Kisiwani and Songo Mnara were declared world heritage sites in 1981, and later the Kondoa Rock-Art Sites in 2006, and Olduvai Gorge and Laetoli Sites as part of the Ngorongoro Conservation Area (NCA) Mixed World Heritage Site in 2010. The Tanzanian National Tourism Policy of 1999 encouraged the development of archaeotourism in its statements 4.4 (cultural objectives) and 5.3 (policy strategies for cultural tourism). Despite these efforts, archaeological sites still receive fewer local and international tourists than national parks and game reserves in their vicinity. For instance, while NCA received about 725,535 tourists in 2018, Olduvai Gorge - four kilometres away - received about 39,500 tourists (NCAA, 2019), and while Selous Game Reserve received about 19,179 tourists in 2018, Kilwa Kisiwani and Songo Mnara in its vicinity received about 3,048 tourists (URT, 2019).

Researchers attribute the low growth in archaeotourism in Sub-Saharan Africa (SSA) to the dearth of knowledge about this market, specifically on what motivates tourists to visit archaeological sites, and the characteristics of the tourists visiting the sites, archaeotourists, as they differ from the dominant nature-based tourists (Ercolano et al., 2018; Sing'ambi and Lwoga, 2018; Lwoga, 2019; Odum and Oguamanam, 2020). Indeed, there has been limited research on archaeotourism markets, although there has been a lot using the push and pull model and empirical facts on eco-tourists and tourists visiting natural attractions that have guided the development and marketing of naturebased tourism. Because natural attractions are characterized by naturally occurring resources and environmental components, and cultural attractions are man-made or influenced by human being, what motivates an individual to visit either attraction may differ (Zhao et al., 2011; Chiang et al., 2015). Even within the cultural tourism realm, archaeotourists may differ from tourists visiting cultural events (Zhao et al., 2011).

The limited research available is inconsistent in explaining archaeotourists. Conventional research has limited archaeotourists to being motivated to find out about the cultural and historic features (Virto et al., 2011; Fagan, 2012; Ross et al., 2017; Ercolano et al., 2018; Odum and Oguamanam, 2020). However, archaeotourism can be enhanced by linking sites to natural attractions, assuming that archaeotourists also consider natural features important (Yun et al., 2008; Cahyadi, 2016; Rapidah et al., 2018). In terms of tourists' profile, based on the distance decay effect, studies agree that archaeotourists have plenty of time to visit a destination (McKercher and du Cros, 2002). However, they disagree on tourists' demographic characteristics, as some (e.g. Silberberg, 1995) argue that archaeotourists are older, more highly educated and on a higher income, while others (e.g. Prentice et al., 1998) argue that they are younger and of a lower socio-economic status. In this regard, the characteristics of

\footnotetext{
${ }^{*}$ Corresponding author
} 
archaeotourists remain unknown, and so it is unclear what would motivate these tourists to visit archaeological sites, where the main attractions are nature-based (typical of most Sub-Saharan African destinations), and how would their motivation differ from that of non-archaeotourists.

The above-mentioned studies focus on sites in regions other than in Sub-Saharan Africa (SSA), and make a legitimate contribution to knowing about the motivation and characteristics of cultural tourists in general, as well as giving interesting insights for archaeotourism marketers. However, their findings cannot be generalized to archaeotourists in SSA. The knowledge generated from past studies in the developed world cannot be used to develop and promote archaeotourism in SSA. Differences between the cultures, economies, history, geopolitics and societies in SSA and those in other regions may influence how tourists perceive archaeological attractions (Timothy and Nyaupane, 2009). In most cases, SSA is renowned for its nature-based tourism, and as natural attractions are the main motive for visiting these locations, archaeological sites are often integrated in the nature-based trips as an added-on experience, but is not the primary reason for travelling (Lwoga, 2019).

This study contributes to this debate. It applies the push and pull motivational model, distance decay theory and uses existing empirical evidence to organize seemingly inconsistent findings to derive hypotheses. It then draws on a sample of international tourists visiting Ngorongoro Conservation Area (NCA) in Tanzania, to examine motivational and profile (demographic and travel characteristics) differences between archaeotourists and non-archaeotourists. NCA is an interesting case study because, apart from being a destination known for its breathtaking crater and rich wildlife, it has recently begun investing in the development of its archaeological sites for tourism, including Olduvai Gorge (URT, 2019). This study gives a broader understanding of what motivates archaeotourists, as opposed to those in the general tourism market who are motivated to visit scenic and nature-based sites in SSA. It also shows archaeotourism marketers how archaeotourists differ from tourists visiting sites that are renowned for their natural attractions in SSA. This information is vital for designing and developing appropriate archaeotourism products and marketing strategies, which will ensure more visits to, and the financial sustainability of, archaeological sites.

\section{LITERATURE REVIEW}

\section{Push and pull theory of motivation}

The dominant theory explaining motivation is the push and pull theory, which posits that intrinsic and extrinsic motivational forces influence a person to participate in a particular tourism activity (Klenosky et al., 2007). A person may have cultural and socio-psychological disequilibrium, an intrinsic motivational force, which may require a travel experience to correct it. On the other hand, a person may decide to visit a place after being pulled by external motivational forces, such as destination attractions and activities that can meet her or his needs (Klenosky et al., 2008). The theory reflects the two major segments of the tourism system, that is, the demand push motives and pull motives that influence a person to visit archaeological sites.

\section{Nature-based, cultural and archaeotourism, and motivations and profiles}

The places that attract tourists to visit can theoretically be of natural, cultural or mixed (natural and cultural) orientation (Lwoga, 2011). While utilizing components of the natural environment to attract tourists is regarded as nature-based tourism, utilizing man-made or culturally influenced tangible and intangible components is referred to as cultural tourism (McKercher and du Cros, 2002; Chiang et al., 2015; Xu and Chan, 2016). Cultural tourists in general usually visit cultural attractions such as performing arts, cultural festivals, and sites and monuments, as well as travelling to study art, experience local foods and lifestyle, and go on a pilgrimage (McKercher and du Cros, 2002; Timothy and Nyaupane, 2009; Chiang et al., 2015). Therefore, archaeotourism emerges as a sub-form of cultural tourism involving visits to archaeological sites (Cahyadi, 2016; Ross et al., 2017). Tourists visiting natural attractions often want to view and experience wildlife and the landscape found there, to escape from a mundane environment, relax, be physically active, learn about nature, and experience a challenging adventure (Tao et al., 2004; Luo and Deng, 2008; Xu and Chan, 2016). In fact, eco-tourists differ from conventional tourists in that they attach great importance to viewing and experiencing natural attractions (Maleski, 2012). On the other hand, studies show that what motivates archaeotourists are compelling stories of the past, the desire to rediscover the past, memorable experiences including escapism, aesthetic and educational experiences, romanticism and fascination with the past, and having an authentic experience of the past (Virto et al., 2011; Fagan, 2012; Ross et al., 2017; Verkerk, 2017; Ercolano et al., 2018). Interestingly, some studies show that archaeotourists are also motivated by natural features such as the nature and exoticness of the sites, which add to tourists' sense of adventure (Yun et al., 2008; Giraudo and Porter, 2010; Cahyadi, 2016). It is thus logical to propose the following:

H1a: Fascination with the past is more important to archaeotourists than to non-archaeotourists.

H1b: Learning about the past is more important to archaeotourists than to non-archaeotourists.

H1c: Relationship enhancement is more important to archaeotourists than to non-archaeotourists.

H1d: Experiencing the authentic past is more important to archaeotourists than to non-archaeotourists.

H1e: Doing research is more important to archaeotourists than to non-archaeotourists.

H1f: Personal development is less important to archaeotourists than to non-archaeotourists.

H1g: Popularity of the site is less important to archaeotourists than to non-archaeotourists.

H1h: Escaping is less important to archaeotourists than to non-archaeotourists.

H1i: Nature and scenery is less important to archaeotourists than to non-archaeotourists.

In recognizing distinct categories of tourists in the 1970s, cultural tourists were generally regarded as better educated and more affluent (McKercher and du Cros, 2002). Even in the 1990s, tourists greatly motivated by cultural attractions were more highly educated and better off (Silberberg, 1995). However, Prentice et al. (1998) found that tourists who visited primarily for cultural purposes had a lower socioeconomic status, while those whose visit was not primarily for cultural purposes were younger and had a higher socio-economic status.

This study considers the following assumptions to guide the investigation:

H2a: Archaeotourists are older than non-archaeotourists.

H2b: Archaeotourists are more educated than non-archaeotourists.

H2c: Archaeotourists are better off than non-archaeotourists.

In terms of travel characteristics, the geographical notion of the distance decay effect explains the travel patterns of archaeotourists in the vicinity of a mainstream nature-based attraction. The notion argues that the difference between the demand and supply side of a location declines rapidly as the distance between them increases (McKercher, 2008). This is because most individuals are unwilling to spend more time and money travelling longer distances if a similar benefit can be obtained nearby (McKercher, 2008). In this study the concept implies that visits to archaeological sites vary according to the distance travelled, in that demand declines exponentially as the distance to tourist attractions increases (McKercher and du Cros, 2002). In this regard, time availability is an important element that can accentuate or minimize the effect of distance decay (McKercher and du Cros, 2002). Most tourists are known to have limited travel time, and so when archaeotourism is an incidental aspect of a trip (typical in NCA), the amount of time a tourist would be willing to allocate to visiting 
archaeological sites would depend on the time they have available (McKercher and du Cros, 2002). This means that tourists who perceive that archaeological sites are far from the iconic Ngorongoro crater in NCA would not visit them, and vice versa. Although the distance decay notion has been criticized in that distance is not an explicit variable in destination choice, it is useful in this study's context, and guides the assumption that archaeotourists in NCA would have more time to travel than non-archaeotourists.

H3a: Archaeotourists have more time to spend at the destination than non-archaeotourists.

H3b: Archaeotourists visit the destination more frequently than non-archaeotourists.

\section{METHODOLOGY}

\section{Study area}

The study was conducted in NCA Mixed World Heritage Site located between $35^{\circ} 30^{\prime} \mathrm{E}$ and $3^{\circ} 15^{\prime} \mathrm{S}$ in Arusha, Tanzania (Figure 1). NCA's 809,440 hectares span a vast expanse of highland plains, savanna, woodlands and forests, from the plains of the Serengeti National Park in the north-west, to the eastern arm of the Great Rift Valley. The area was established in 1959 as a multiple land-use area, with wildlife coexisting with semi-nomadic Maasai pastoralists practicing traditional livestock grazing. It includes the spectacular Ngorongoro Crater, which is the world's largest caldera of global importance for biodiversity conservation, due to the presence of globally threatened species, the density of wildlife, including the migratory wildebeest, zebras, gazelles, rhinos, giraffes, lions, leopards, hyenas, buffalos and elephants, and a variety of birds species.

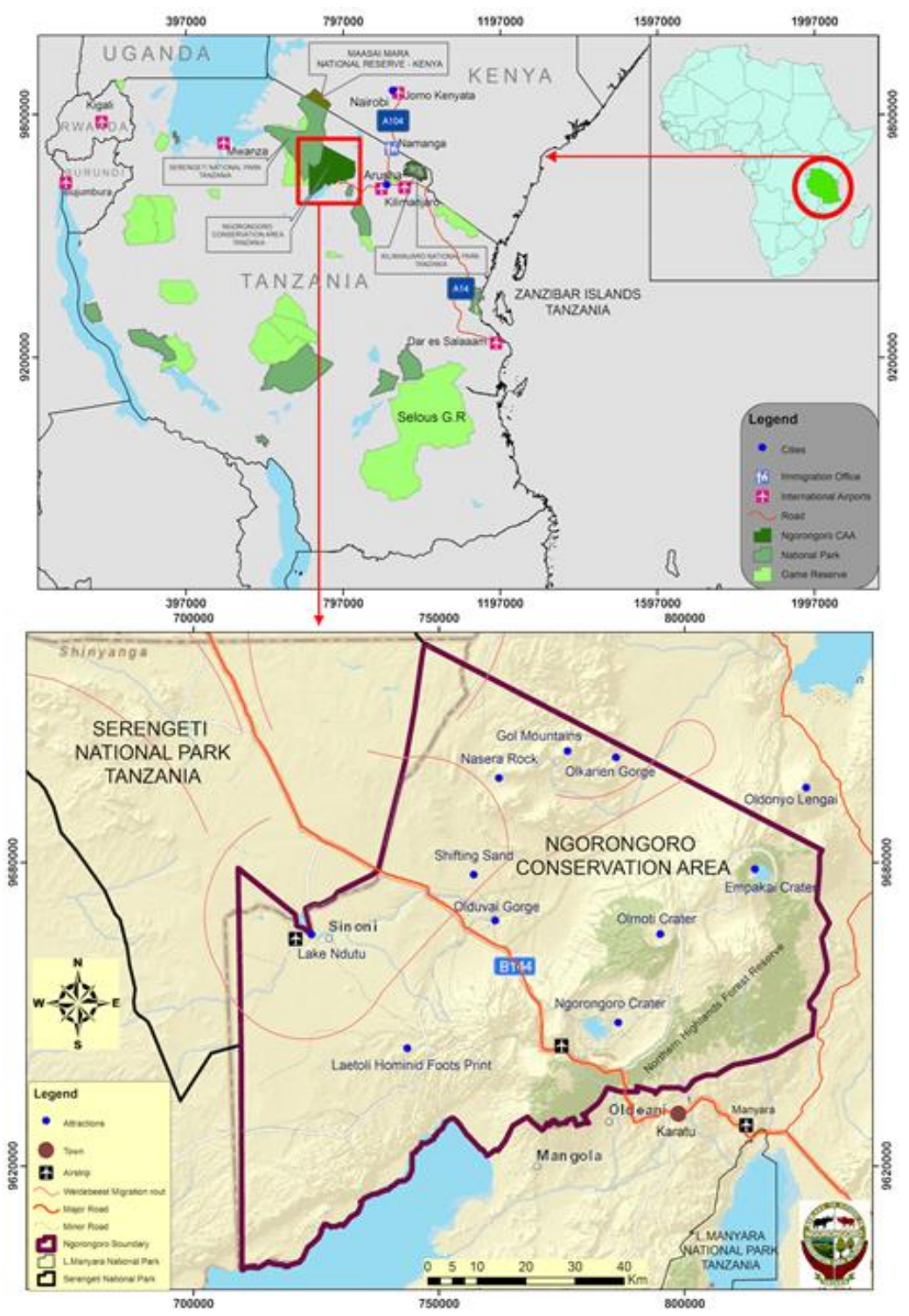

Figure 1. The Map of Ngorongoro Conservation Area (Source: Mwankunda, 2019)

Extensive archaeological research in NCA for over 80 years has yielded a long sequence of evidence of human evolution and humanenvironment dynamics, including early hominid footprints dating back 3.6 million years, and a sequence of diverse and evolving hominin species in Olduvai Gorge, ranging from Australopiths such as Zinjanthropus boisei to the Homo lineage that includes Homo habilis. There is also an early form of Homo sapiens at Lake Ndutu documenting the development of stone technology and the transition to the use of iron. NCA is therefore rich in terms of cultural heritage resources, especially, archaeological ones (Figure 2).

NCA is legally protected primarily by the NCA Ordinance of 1959 under the Ngorongoro Conservation Area Authority (NCAA). However, the Antiquities Division (AD) of the Ministry of Natural Resources and Tourism (MNRT) has been responsible for the management and protection of the archaeological resources in the NCA. Recently however, after noting the failure to develop the site properly, the AD handed over the protection, conservation and development functions of the archaeological resources to the NCAA. In terms of tourism in general, NCA noted an increase in tourist numbers from 332,469 in 2014 to 725,535 in 2018, most of them to visit the-must-visit 
Ngorongoro Crater. Archaeological sites such as the famous Olduvai Gorge - under the AD - used to receive less than 50,000 tourists, as for instance it received 39,500 tourists in 2018 (NCAA, 2019). However, after being handled over to the NCAA, and with recent developments that the NCAA did to archaeological sites, Olduvai Gorge for instance attracted 939,084 tourists in 2019 compared with 32,012 in 2016, making it the top cultural site in Tanzania (URT, 2019). This means that archaeotourism has just begun to be well established in NCA.

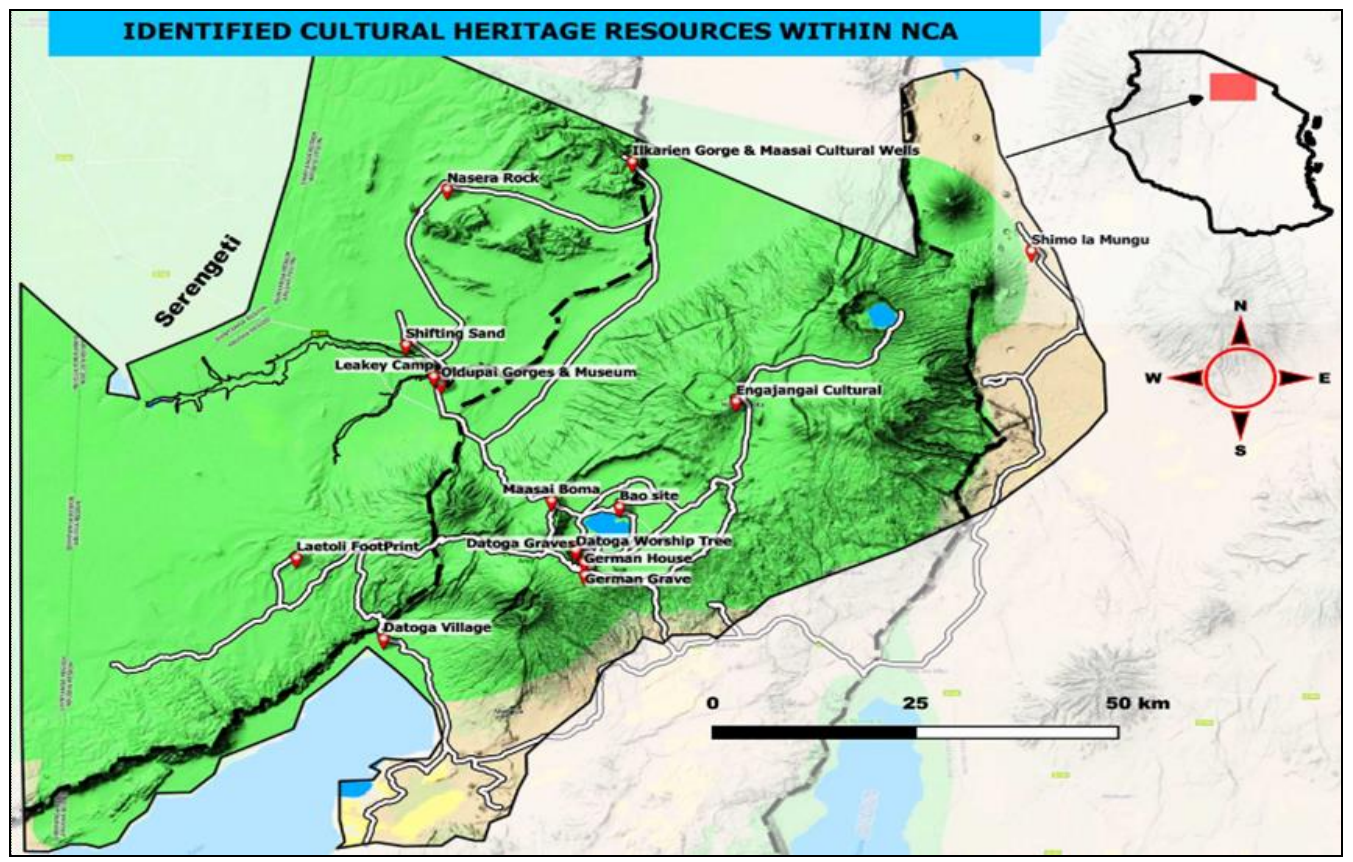

Figure 2. Ngorongoro conservation area showing cultural heritage resources (Source: Mwankunda, 2019)

\section{Research design, sample, data collection and analysis procedures}

This study is basically a cross-sectional research that utilized a questionnaire survey design. The target population was international tourists visiting NCA. The sample size was 252 tourists. The study applied random sampling at the exit point to involve tourists departing from NCA.

A self-administered questionnaire was given to tourists who agreed to participate in the study, with assurance to the anonymity of their responses. Tourists completed the questionnaires and delivered them by hand to the researchers. The questionnaire was prepared in English and contained both scaled and categorical measures to capture the variables of interest. The scale had an initial que stion that was intended to measure whether the tourist visited archaeological sites while in NCA or not. This was basically a dummy variable $(1=$ No, 2 = Yes). The scale also measured motivational variables, such as an interest in the past, personal advancement, learning, expe riencing an authentic past, popularity of the place, doing research, the scenery, and escape. Measures related to the motivational variables were adopted from Chiang et al. (2015), Virto et al. (2011), and Ercolano et al. (2018). The questions regarding motivational scales asked respondents to rate the importance of motivation (measure) in their decision to visit NCA, by circling the appropriate response, such as Not Important at All (value of 1), Not Important (2), Not Sure (3), Important (4), and Extremely Important (5). It also involved scales that measured demographic variables such as sex (dummy variable), age, education level and monthly income (ordinal variables), and travel characteristics, such as tourists' origin (nominal variable) and travel frequency and length of visit (ratio variables). The questionnaire was pre-tested before being implemented. It was first sent to three tourism experts at the University of Dar es Salaam and NCA to review and scrutinize it. It was also administered initially to ten international tourists at NCA. Several measurement items were reshaped and reworded to improve measurements. The data were collected in August and September 2019, within the peak season in Tanzania.

Data were cleaned, coded and checked for appropriateness. Descriptive statistics including skewness and kurtosis, mean and standard deviation (SD) were applied to check the data's distributional behaviour with regard to normality. Frequency and percentage statistics were used to discover the prevalence of demographic and travel characteristics. Exploratory Factor Analysis (EFA) was used to analyse scaled data and the underlying dimensions of tourists' motivation. To analyse the differences in tourists' motivation and profile (demographic and travel characteristics) between archaeotourists and non-archaeotourists, their responses relating to the abovementioned variables were compared using two-sided $t$-tests, Mann-Whitney $U$ tests and chi-square tests with Fischer's exact tests. A $P$ value of less than 0.05 was considered statistically significant, and mean statistics were applied. To ensure validity, especially content validity, the research was carefully defined through reviewing the theoretical and empirical literature and through pre-testing the questionnaire, as mentioned earlier. Cronbach's Alpha was used to test reliability.

\section{RESULTS}

\section{Demographic and travel characteristics of respondents}

The demographic characteristics of the respondents are shown in Table 1. The majority were aged between 21 and 60 (about $83 \%$ ) with a Bachelor or Masters Degree (77\%) and a monthly income of over USD 5,000 (71\%). This reflects the major categories of visitors to NCA, who are basically those who earn a salary, are well-educated and have a relatively high income. The travel characteristics of the respondents are shown in Table 2. Most of them came from North America (37.7\%, dominated by those from the United States of America (31\%), followed closely by those who came from Europe, with Italians dominating, followed by Germans, French, Spanish and British. As shown in Table 2, tourists from African and South American countries followed with 3.6\% each. In terms of those coming from Africa, Kenyans dominated. There is a fairly equal distribution of respondents in terms of visiting archaeological sites, whereby 53\% visited archaeological sites while in NCA and $47 \%$ did not (see Table 2). In terms of travel frequency, the majority of respondents visited NCA once every few years (77.5\%), followed by those who visited once a year $(15.9 \%)$. Few respondents visited more than once a year (4.8\%). The majority of respondents spent at least a full two to three days in NCA (78.9\%), followed by those who spent half a day (15.5\%), while a few spent four or more days $(5.6 \%)$. 
Table 2. Travel characteristics $(N=252)$

Table 1. Demographic characteristics $(N=252)$

\begin{tabular}{|c|c|}
\hline Characteristics & \% \\
\hline Sex & 50.4 \\
\hline Female & 49.6 \\
\hline Male & \\
\hline Age & 2.8 \\
\hline $21-40$ & 57.2 \\
\hline $41-60$ & 26.5 \\
\hline$>60$ & 13.5 \\
\hline Education level & \\
\hline Primary & 1.6 \\
\hline Secondary & 14.3 \\
\hline Bachelor Degree & 46.4 \\
\hline Master Degree & 31.3 \\
\hline PhD & 6.4 \\
\hline Monthly income (USD) & \\
\hline No income & 6.0 \\
\hline $1-5,000$ & 22.6 \\
\hline 5,001 - 10,000 & 36.1 \\
\hline$>10,000$ & 35.3 \\
\hline
\end{tabular}
Characteristics

\begin{tabular}{|c|c|}
\hline Characteristics & $\%$ \\
\hline \multicolumn{2}{|l|}{ Origin } \\
\hline North America & 37.8 \\
\hline United States of America & 31.0 \\
\hline Mexico & 3.2 \\
\hline Other American countries (Albania, Bahamas, Barbados, Belize, Canada, Cuba, Honduras, Nicaragua) & 3.6 \\
\hline Australia & 2.8 \\
\hline Europe & 37 \\
\hline Germany & 9.1 \\
\hline Italy & 12.3 \\
\hline France & 6.8 \\
\hline Spain & 1.6 \\
\hline United Kingdom & 1.2 \\
\hline Other European Countries & 6 \\
\hline Asia & 12 \\
\hline India & 4.0 \\
\hline Singapore & 3.6 \\
\hline China & 1.6 \\
\hline Other Asian Countries & 2.8 \\
\hline South America (Argentina, Brazil, Bolivia and Chile) & 3.6 \\
\hline Middle East (Israel, UAE, Saudi Arabia) & 3.2 \\
\hline Africa & 3.6 \\
\hline Kenya & 1.6 \\
\hline Uganda & 1.2 \\
\hline Other African countries & 1.2 \\
\hline \multicolumn{2}{|l|}{ Visit to archaeological site } \\
\hline Yes & 53 \\
\hline No & 47 \\
\hline \multicolumn{2}{|l|}{ Travel frequency } \\
\hline First time & 1.6 \\
\hline Once in a few years & 77.4 \\
\hline Once a year & 15.9 \\
\hline Twice a year & 4.4 \\
\hline Three or more times a year & 0.8 \\
\hline \multicolumn{2}{|l|}{ Length of visit } \\
\hline Half a day & 15.5 \\
\hline Full day & 31.7 \\
\hline Two to three days & 47.2 \\
\hline Four to five days & 2.8 \\
\hline More than five days & 2.8 \\
\hline
\end{tabular}

\section{Motivations for visiting NCA in general}

Descriptive statistics based on mean and standard deviation shown in Table 3 indicate that, on average, appreciation of nature is the most important reason for tourists visiting Ngorongoro, with a mean value of 4.32, SD 0.6074, followed by learning about the past, with a mean value of 4.27 and viewing beautiful scenery, with a mean value of 4.25 . Other items that have mean values of 4.0 and over relate to learning, experiencing nature, including unique geological features, and escaping. These findings show that natural resources, such as the wildlife, beautiful scenery and landscape are the most important attractions in NCA, and experiencing nature and escaping are the most important motivations. In terms of learning, the past dominates, implying that archaeological sites and experiencing the past can have a role in motivating tourists to visit NCA with the purpose of learning. EFA was used to summarize motivational measurement items into underlying dimensions regarding reasons for visiting NCA. Bartlett's sphericity test checked whether the correlation matrix of the measurement items was an identity matrix. As shown in Table 3, the $p$ value for the Bartlett test was below 0.05 , indicating that the dataset under consideration was not an identity matrix. The Kaiser-Meyer-Olkin (KMO) test of sample adequacy was applied to check whether the sample was adequate. The KMO value was 0.813 , which is over 0.6 , indicating that the dataset is suitable for factor analysis.

Varimax rotation was used to derive factor solution. The results indicate that the motivational items, all loaded with values above the average of 0.5 , can be grouped into nine (9) factors. The factors are: (i) fascination with the past, which include seven items relating to the motive to view past objects, connect with and experience the past and satisfy romantic feelings about the past; (ii) personal advancement, which includes four items relating to the motive to experience solitude, think and focus on personal values; (iii) learning, which involves seven items relating to the motive to develop one's knowledge, explore the unknown, escape from routine and learn about new things and a different culture; (iv) encountering the authentic past, which includes items relating to the motive to seek authentic experiences, see and experience authentic past objects and authentic connections with the past; (v) popularity of the site, which involves four items relating to the site having world heritage status and being popular and famous; (vi) doing research, which includes three items relating to the motive to experience a historic age; (vii) nature and scenery which involves three items relating to the motive to view and appreciate nature and beautiful scenery, and experience geological landscapes; (viii) relationship enhancement, which includes three items relating to the motive to have fond memories and strengthen relationships with friends and relatives; and (ix) escape, which include two items relating to the motive to relax and be reenergized and regenerated. Cronbach's Alpha test of the nine factors were all over 0.6, indicating the measurement had satisfactory reliability.

\section{Differences in motivation between archaeotourists and non-archaeotourists in NCA}

An independent sample t-test was carried out on factors to determine whether tourists who visited archaeological sites and those who did not while in NCA were significantly different in terms of motivational factors, thus testing $H l a, H 1 b, H 1 c, H 1 d, H 1 e, H 1 f, H 1 g$ and $H I h$. Table 4 shows that archaeotourists attached greater importance to experiencing an authentic past $H 1 d\left(M_{1}=4.02, M_{2}=3.78\right)$, enhancing relationships HIc $\left(M_{1}=3.96, M_{2}=3.59\right)$ and doing research Hle $\left(M_{1}=3.52, M_{2}=3.09\right)$ than non-archaeotourists. On the other hand, they considered nature and scenery $H 1 h\left(M_{1}=4.19, M_{2}=4.26\right)$ as less important. The findings also show that there are no significant differences in the importance they attach to the motive relating to fascination in general, personal advancement, popularity of the site, learning and escape. Thus, the results 
supported Hlc, HId, Hle and HIh. An independent sample t-test was also extended to each individual motivational item. The findings are indicated in Table 4. Archaeotourists attach greater importance of fascination relating to motives, such as listening to stories of the past $\left(M_{l}=\right.$ $\left.3.82, M_{2}=3.43\right)$, spending time in the past $\left(M_{1}=3.67, M_{2}=3.32\right)$, enjoying looking at past objects $\left(M_{1}=3.78, M_{2}=3.41\right)$ and experiencing the past $\left(M_{1}=3.70, M_{2}=3.50\right)$. They also attach greater importance to connecting with the authentic past $\left(M_{1}=4.06, M_{2}=3.73\right)$, feeling inner harmony $\left(M_{1}=4.05, M_{2}=3.45\right)$, and having fond memories $\left(M_{1}=4.09, M_{2}=3.71\right)$. On the other hand, archaeotourists consider the following as being less important compared with non-archaeotourists: viewing beautiful scenery $\left(M_{1}=4.20, M_{2}=4.27\right)$ and appreciating nature better $\left(M_{1}=4.32, M_{2}=4.38\right)$. Interestingly, they considered experiencing geological landscapes $\left(M_{l}=4.23, M_{2}=3.98\right)$ as important.

Table 3. Factor analysis, descriptive and reliability statistics

\begin{tabular}{|c|c|c|c|c|c|c|c|c|c|c|c|c|}
\hline \multirow{2}{*}{ Factor and Items } & \multirow[t]{2}{*}{ Overall Mean } & \multirow[t]{2}{*}{ SD } & \multicolumn{9}{|c|}{ Factors } & \multirow[t]{2}{*}{ CA } \\
\hline & & & 1 & 2 & 3 & 4 & 5 & 6 & 7 & 8 & 9 & \\
\hline Fascination & & & & & & & & & & & & 0.926 \\
\hline I am fascinated by stories of the past & 3.64 & 1.11 & 0.896 & & & & & & & & & \\
\hline To spend time in the past & 3.50 & 1.21 & 0.894 & & & & & & & & & \\
\hline \begin{tabular}{|l} 
To enjoy looking at past objects \\
\end{tabular} & 3.61 & 1.14 & 0.890 & & & & & & & & & \\
\hline To feel deeply connected to the past & 3.45 & 1.16 & 0.753 & & & & & & & & & \\
\hline To experience authenticity of the past & 3.60 & 1.09 & 0.717 & & & & & & & & & \\
\hline \begin{tabular}{|l|} 
To connect with our origins \\
\end{tabular} & 3.37 & 1.15 & 0.590 & & & & & & & & & \\
\hline \begin{tabular}{|l|} 
Personal advancement \\
\end{tabular} & & & & & & & & & & & & 0.927 \\
\hline To develop personal values & 3.79 & 0.95 & & 0.888 & & & & & & & & \\
\hline To think about personal values & 3.86 & 0.92 & & 0.884 & & & & & & & & \\
\hline \begin{tabular}{|l|} 
To experience solitude \\
\end{tabular} & 3.81 & 1.03 & & 0.881 & & & & & & & & \\
\hline \begin{tabular}{|l|l} 
To focus on myself \\
\end{tabular} & 3.89 & 0.84 & & 0.714 & & & & & & & & \\
\hline \begin{tabular}{|l|} 
Learning \\
\end{tabular} & & & & & & & & & & & & 0.831 \\
\hline To learn new things & 4.18 & 0.76 & & & 0.774 & & & & & & & \\
\hline \begin{tabular}{|l|} 
To learn about the past \\
\end{tabular} & 4.27 & 0.69 & & & 0.759 & & & & & & & \\
\hline To have a deep understanding of the past & 4.19 & 0.77 & & & 0.676 & & & & & & & \\
\hline \begin{tabular}{|l} 
To develop my knowledge \\
\end{tabular} & 4.18 & 0.76 & & & 0.669 & & & & & & & \\
\hline To escape from routine & 4.02 & 0.94 & & & 0.612 & & & & & & & \\
\hline \begin{tabular}{|l|} 
Encounter authentic past \\
\end{tabular} & & & & & & & & & & & & 0.883 \\
\hline \begin{tabular}{|l|} 
To connect with the past \\
\end{tabular} & 3.90 & 0.99 & & & & 0.899 & & & & & & \\
\hline To see authentic past objects & 3.92 & 0.96 & & & & 0.842 & & & & & & \\
\hline To experience the authentic past & 3.86 & 0.91 & & & & 0.805 & & & & & & \\
\hline To experience archaeological sites & 3.94 & 0.98 & & & & 0.682 & & & & & & \\
\hline Popularity of site & & & & & & & & & & & & 0.825 \\
\hline This place is a World Heritage Site & 3.96 & 0.96 & & & & & 0.818 & & & & & \\
\hline It has famous attractions & 3.77 & 0.91 & & & & & 0.689 & & & & & \\
\hline It is a popular site & 3.99 & 0.91 & & & & & 0.683 & & & & & \\
\hline To contribute to conservation & 3.75 & 0.94 & & & & & 0.615 & & & & & \\
\hline \begin{tabular}{|l|} 
Research \\
\end{tabular} & & & & & & & & & & & & 0.702 \\
\hline It is part of my research project & 2.74 & 1.39 & & & & & & 0.845 & & & & \\
\hline I have a specific interest in the past & 3.22 & 1.26 & & & & & & 0.797 & & & & \\
\hline \begin{tabular}{|l|} 
To experience a historic age \\
\end{tabular} & 3.92 & 0.90 & & & & & & 0.479 & & & & \\
\hline \begin{tabular}{|l} 
To appreciate nature better \\
\end{tabular} & 4.32 & 0.61 & & & & & & & 0.763 & & & \\
\hline To experience geological landscapes & 4.11 & 0.70 & & & & & & & 0.647 & & & \\
\hline \begin{tabular}{|l|} 
Relationship enhancement \\
\end{tabular} & & & & & & & & & & & & 0.685 \\
\hline To feel inner harmony & 3.76 & 1.15 & & & & & & & & 0.800 & & \\
\hline \begin{tabular}{|l|} 
To have fond memories \\
\end{tabular} & 3.91 & 0.89 & & & & & & & & 0.604 & & \\
\hline To strengthen relations with relatives & 3.69 & 1.13 & & & & & & & & 0.552 & & \\
\hline Escape & & & & & & & & & & & & 0.763 \\
\hline To relax & 4.01 & 0.85 & & & & & & & & & 0.800 & \\
\hline To be re-energized and regenerated & 3.86 & 0.89 & & & & & & & & & 0.675 & \\
\hline
\end{tabular}

\section{Differences in characteristics between archaeotourists and non-archaeotourists}

A series of Chi-square tests was conducted to compare the two groups based on demographic and travel characteristics. As shown in Table 5, the results indicated that there is a significant difference between the two groups in terms of income and age, whereby archaeotourists are older $H 2 a\left(M_{1}=3.67, M_{2}=3.30\right)$ and better off $H 2 c\left(M_{1}=3.14, M_{2}=2.86\right)$ than non-archaeotourists. In terms of travel characteristics, there is a significant difference in length of visit $H 3 a$ to NCA, whereby archaeotourists had more time to spend in NCA than non-archaeotourists $\left(M_{1}=2.67, M_{2}=2.22\right)$.

\section{DISCUSSION}

The findings suggest that, in general, nature is undeniably the most important pull motivational force for tourists visiting NCA. One important push motivational force was escape, which is mostly associated with relaxing. However, the most important push motivational force appears to be the desire to learn not only about nature, but also notably about the past. EFA indicated the presence of the nine (9) dimensions of fascination with the past, personal advancement, learning, encountering authenticity, site popularity, doing research, nature, enhancing relationships and escaping. The results suggest that, although both groups generally consider fascination, personal advancement, learning, escape and popularity of the site to be important motives, archaeotourists attach greater importance to experiencing the authentic past, doing research and enhancing relationships than non-archaeotourists, but of less importance to the former was viewing nature and the scenery. The results thus support Hlc, Hld, Hle and Hli. Although the results did not support the notion of fascination, they showed that some of its items such as stories of the past were considered more important by archaeotourists than non-archaeotourists. 
Table 4. Independent sample t-test results

\begin{tabular}{|c|c|c|c|c|c|c|c|}
\hline Factor and Items & Overall Mean & SD & $\begin{array}{c}\text { Mean Visitor } \\
N=133\end{array}$ & $\begin{array}{c}\text { Mean Non-visitor } \\
N=119\end{array}$ & $\begin{array}{c}p- \\
\text { value }\end{array}$ & Hypothesis & Decision \\
\hline Fascination & & & 3.60 & 3.41 & 0.314 & HIa & NOT SUPPORTED \\
\hline I am fascinated by stories of past & 3.64 & 1.11 & 3.82 & 3.43 & 0.013 & & \\
\hline To spend time in the past & 3.50 & 1.21 & 3.67 & 3.32 & $\mathbf{0 . 0 3 1}$ & & \\
\hline \begin{tabular}{|l} 
To enjoy viewing past objects \\
\end{tabular} & 3.61 & 1.14 & 3.78 & 3.41 & 0.015 & & \\
\hline To feel deep connection with past & 3.45 & 1.16 & 3.42 & 3.49 & 0.688 & & \\
\hline To seek experience of the past & 3.60 & 1.09 & 3.70 & 3.50 & 0.071 & & \\
\hline To connect with our origins & 3.37 & 1.15 & 3.39 & 3.35 & 0.592 & & \\
\hline \begin{tabular}{|l|} 
Personal value advancement \\
\end{tabular} & & & 3.78 & 3.90 & 0.773 & H1e & NOT SUPPORTED \\
\hline To develop personal values & 3.79 & 0.95 & 3.74 & 3.85 & 0.687 & & \\
\hline To think about personal values & 3.86 & 0.92 & 3.81 & 3.91 & 0.879 & & \\
\hline \begin{tabular}{|l} 
To experience solitude \\
\end{tabular} & 3.81 & 1.03 & 3.71 & 3.91 & 0.477 & & \\
\hline \begin{tabular}{|l} 
To focus on myself \\
\end{tabular} & 3.89 & 0.84 & 3.87 & 3.92 & 0.804 & & \\
\hline \begin{tabular}{|l|} 
Learning \\
\end{tabular} & & & 4.14 & 4.21 & 0.260 & $H 1 b$ & NOT SUPPORTED \\
\hline \begin{tabular}{|l|} 
To learn new things \\
\end{tabular} & 4.18 & 0.76 & 4.18 & 4.19 & 0.993 & & \\
\hline \begin{tabular}{|l|} 
To learn about the past \\
\end{tabular} & 4.27 & 0.69 & 4.19 & 4.36 & 0.061 & & \\
\hline To have deep understanding of the past & 4.19 & 0.77 & 4.16 & 4.22 & 0.636 & & \\
\hline \begin{tabular}{|l} 
To develop my knowledge \\
\end{tabular} & 4.18 & 0.76 & 4.08 & 4.29 & 0.060 & & \\
\hline To escape routine & 4.02 & 0.94 & 3.98 & 4.08 & 0.362 & & \\
\hline \begin{tabular}{|l} 
Encounter authentic past \\
\end{tabular} & & & 4.02 & 3.78 & $\mathbf{0 . 0 2 7}$ & H1d & SUPPORTED \\
\hline To connect with the past & 3.90 & 0.99 & 4.06 & 3.73 & 0.014 & & \\
\hline To see authentic past objects & 3.92 & 0.96 & 4.03 & 3.80 & 0.192 & & \\
\hline To experience authenticity of past & 3.86 & 0.91 & 3.94 & 3.77 & 0.134 & & \\
\hline To experience archaeological sites & 3.94 & 0.98 & 4.07 & 3.81 & 0.113 & & \\
\hline \begin{tabular}{|l|} 
Popularity of site \\
\end{tabular} & & & 3.85 & 3.88 & 0.994 & H1g & NOT SUPPORTED \\
\hline This place is a World Heritage Site & 3.96 & 0.96 & 3.90 & 4.02 & 0.559 & & \\
\hline \begin{tabular}{|l|} 
It has famous attractions \\
\end{tabular} & 3.77 & 0.91 & 3.87 & 3.67 & 0.060 & & \\
\hline It is a popular site & 3.99 & 0.91 & 3.97 & 4.02 & 0.811 & & \\
\hline To contribute to conservation & 3.75 & 0.94 & 3.67 & 3.83 & 0.355 & & \\
\hline \begin{tabular}{|l|} 
Research \\
\end{tabular} & & & 3.52 & 3.09 & 0.000 & HIf & SUPPORTED \\
\hline It is part of my research project & 2.74 & 1.39 & 3.08 & 2.44 & 0.000 & & \\
\hline I have specific interest for the past & 3.22 & 1.26 & 3.41 & 3.05 & $\mathbf{0 . 0 5 0}$ & & \\
\hline To experience a historic age & 3.92 & 0.90 & 4.07 & 3.78 & $\mathbf{0 . 0 2 9}$ & & \\
\hline To appreciate nature better & 4.32 & 0.61 & 4.32 & 4.38 & $\mathbf{0 . 0 5 3}$ & & \\
\hline To experience geological landscapes & 4.11 & 0.70 & 4.23 & 3.98 & 0.001 & & \\
\hline $\begin{array}{l}\text { Relationship enhancement } \\
\end{array}$ & & & 3.96 & 3.59 & 0.000 & H1 & SUPPORTED \\
\hline \begin{tabular}{|l|} 
To feel inner harmony \\
\end{tabular} & 3.76 & 1.15 & 4.05 & 3.45 & 0.000 & & \\
\hline To have fond memories & 3.91 & 0.89 & 4.09 & 3.71 & 0.000 & & \\
\hline To strengthen relations with relatives & 3.69 & 1.13 & 3.74 & 3.63 & 0.508 & & \\
\hline \begin{tabular}{|l|l|} 
Escape \\
\end{tabular} & & & 3.95 & 3.91 & 0.425 & H1h & NOT SUPPORTED \\
\hline To relax & 4.01 & 0.85 & 4.07 & 3.94 & 0.092 & & \\
\hline To be re-energized and regenerated & 3.86 & 0.89 & 3.84 & 3.88 & 0.479 & & \\
\hline
\end{tabular}

Table 5. Differences in demographic and travel characteristics between the two groups

\begin{tabular}{|c|c|c|c|c|c|c|c|}
\hline Tourist Characteristics & Overall Mean & SD & Mean Visitor $N=133$ & Mean Non-visitor $N=119$ & $p$-value & Hypothesis & Decision \\
\hline \multicolumn{8}{|l|}{ Demographic Characteristics } \\
\hline Age & 3.50 & 1.48 & 3.67 & 3.30 & 0.042 & $H 2 a$ & SUPPORTED \\
\hline Education & 4.27 & 0.84 & 4.33 & 4.19 & 0.219 & $H 2 b$ & NOT SUPPORTED \\
\hline Income & 3.01 & 0.91 & 3.14 & 2.86 & 0.014 & $H 2 c$ & SUPPORTED \\
\hline \multicolumn{8}{|l|}{\begin{tabular}{|l|} 
Travel Characteristics \\
\end{tabular}} \\
\hline Travel frequency & 2.25 & 0.60 & 2.24 & 2.27 & 0.764 & $H 3 a$ & NOT SUPPORTED \\
\hline Length of visit & 2.46 & 0.88 & 2.67 & 2.22 & 0.000 & $H 3 b$ & SUPPORTED \\
\hline
\end{tabular}

This means that, while archaeotourists at NCA are highly motivated by experiencing the authentic past, enhancing relationships and listening to stories of the past, non-archaeotourists are highly motivated by viewing nature and the scenery and doing research. The results corroborate earlier findings by Ross et al. (2017) and reflect Virto et al. (2011) as well as Cahyadi.'s (2016) conceptualization that archaeotourists desire to rediscover the past, seek memorable and authentic experiences, and satisfy their romantic feelings about the past. This implies that Olduvai Gorge site in NCA offers fascinating stories about the past, which is enhanced by the museum telling interesting, memorable and compelling stories, and by authentic objects. In addition, the results suggest that archaeotourists are motivated by opportunities to strengthen their relationships, meaning that NCA can offer opportunities for tourists to interact with their friends and relatives.

Interestingly, archaeotourists were not completely uninterested in natural attractions, thereby supporting earlier findings by Rapidah et al. (2018), Cahyadi (2016), Giraudo and Porter (2010) and Yun et al. (2008). The results in this study specifically add to past research that geological features are more important to archaeotourists than to non-archaeotourists. In fact, the geological perspective enhances the interpretation and experience of archaeological objects. In recognition of this fact, in 2017, the NCA begun to package geological features and landscapes as geotourism and acquired the status of a UNESCO Global Geopark, which seems to draw tourists interested in archaeological attractions. The results also show that archaeotourists are older and better off that non-archaeotourists, thereby supporting $H 2 a$ and $H 2 c$. This result corroborates an earlier finding (Silberberg, 1995) that tourists motivated by culture have a higher income, and so are likely to pay for extra packages, such as those involving archaeological sites, when visiting Ngorongoro crater. At NCA, visiting the popular crater costs $\$ 250$ per 7-seater vehicle, on top of which tourists wanting to visit archaeological sites would have to pay $\$ 30$. The consideration of travel characteristics was unique to this study, which found that archaeotourists generally had more time and so could stay longer in NCA. This is explained by distance decay and time availability notions (McKercher and du Cros, 2002). In NCA, a tourist needs to drive for about an hour along a $4 \mathrm{~km}$ road from the crater to 
Olduvai Gorge and for 2 hours along the $7 \mathrm{~km}$ road to Laetoli. Given that the road conditions range from fair to poor, from the point of view of accessing these sites, those with more time to spend in NCA would not perceive them as being far, and would therefore consider visiting them. In addition, because archaeotourists are older, they would need more time to walk around them. The exotic and hard-to-access remoteness of archaeological sites found earlier by Cahyadi (2016) that motivate visits to archaeological sites do not feature in the case of NCA. Perhaps, as shown earlier, in NCA the most important motives are still nature-based, although the archaeological sites' proximity to the crater matters.

\section{CONCLUSION}

The study contributes to the debate on the motivations and profiles of cultural tourists, and argues that archaeotourists are heterogeneous as they attach great importance not only to learning about a culture by listening to fascinating stories of the past and looking at past objects, but also to doing research, enhancing relationships and learning about nature, especially the geological features. Compared with non-archaeotourists, they have more time to visit places, are older and better off. The study shows the importance of push and pull conceptualization of motivations, and of distance decay notion in explaining archaeotourism market in the SSA context. An important marketing implication to be drawn from this research is that, if attracting more archaeotourists is desired, marketers should attempt to meet these specific needs by providing relevant learning activities for travellers, emphasizing that the sites are family-friendly. In fact, providing cultural and educational events and entertainment will not only enhance tourists' relationships, but will also give them a stronger motive to visit archaeological sites.

They should also maximize the opportunities for encountering the past through storytelling, and exhibiting authentic objects and localities. Importantly, they should explain that geological features can also be seen at archaeological sites, and so brochures and websites should emphasize geological scenes. While portraying the exoticness of archaeological sites is necessary to satisfy the need to escape and to learn, this should be done strategically by emphasizing that they are near mainstream nature-based attractions and can be easily accessed. In addition, the needs of older tourists should be considered. The limited sample of international tourists in NCA may prevent generalization of the findings to all archaeotourists visiting Tanzania, but this study's findings could still be useful to sites with similar contexts. Motivational and demographic and travel-based factors are contextual, and so their role in explaining the differences between archaeotourists and nonarchaeotourists should always take the socio-cultural context into account. Future contributions to gaining an understanding of the different motivations and profiles of archaeotourists should include samples of different tourism contexts to ascertain the moderating effect of context.

\section{REFERENCES}

Cahyadi, H.S. (2016). Integrating archaeotourism with geotourism development in Bantimurung National Park, South Sulawesi province. Proceedings, The $12^{\text {th }}$ Biennial Conference of Hospitality and Tourism Industry in Asia (ATF-16), Asia Tourism Forum. Atlantis Press. http://dx.doi.org/10.2991/atf-16.2016.86

Chiang, C., Ming-Yuan, W., Chong-Foi, L., \& Ying-Chioh, C. (2015). Assessing travel motivations of cultural tourists: A factor-cluster segmentation analysis Journal of Information and Optimization Sciences, 36 (3), 269-282. http://dx.doi.org/10.1080/02522667.2014.996028

Ercolano, S., Gaeta, G.L., \& Parenti, B. (2018). Pompeii dilemma: A motivation-based analysis of tourists' preference for "superstar" archaeological attractors of less renowned archaeological sites in the Vesuvius area. International Journal of Tourism Research, 20 (3), 345-354. http://dx.doi.org/10.1002/jtr.2186

Fagan, B.M. (2012). Archaeology: A Brief Introduction. Boston, MA: Pearson.

Giraudo, R.F., \& Porter, B.W. (2010). Archaeotourism and the crux of development. Anthropology News, 51 (8), 7-8. http://dx.doi.org/10.1111/j.1556-3502.2010.51807.x

Klenosky, D.B., LeBlanc, C.I., Vogt, C.A., \& Schroeder, H.W. (2008). Factors that attract and repel visitation to urban recreation sites: A framework for research. In C. Le Blanc \& C. Vogt (Comp.), Proceedings of the 2007 North-Eastern Recreation Research Symposium, 39-45.

Luo, Y., \& Deng, J. (2008). The new environmental paradigm and nature-based tourism motivation. Journal of Travel Research, 46 (4), $392-402$. http://dx.doi.org/10.1177/0047287507308331

Lwoga, N.B. (2011). Tourism: Meaning, Practices and History. Dar es Salaam: Dar es Salaam University Press.

Lwoga, N.B. (2019). International demand and its motives for African community-based cultural heritage tourism. GeoJournal of Tourism and Geosites, 25 (2), 408-428. http://dx.doi.org/10.30892/gtg.25212-370

Maleski, G. (2012). A comparative analysis of the travel motivations of ecotourists and conventional tourists in Wisconsin. Paper, Travel and Tourism Research Association, Advancing Tourism Research Globally 9.

McKercher, B. (2008). The implicit effect of distance on tourist behavior: a comparison of short and long-haul pleasure tourists to Hong Kong. Journal of Travel and Tourism Marketing, 25 (3-4), 367-381. http://dx.doi.org/10.1080/10548400802508473

McKercher, B., \& du Cross, H. (2002). Cultural Tourism: The Partnership and Cultural Heritage Management. New York: The Haworth Press

Mwankunda, J. (2019). Ngorongoro Conservation Area Archaeotourism. NCAA Annual Report, Ngorongoro.

Nyaupane, G.P., White, D., \& Budruk, M. (2006). Motive-based tourist market segmentation: An application to Native American cultural heritage sites in Arizona, USA. Journal of Heritage Tourism, 1 (2), 81-99. http://dx.doi.org/10.2167/jht010.0

Oehmichen-Bazan, C. (2018). Archaeology and tourism. In Varela, S.L.L. (Ed.), The Encyclopedia of Archaeological Sciences, John Wiley \& Sons, 1-3 http://dx.doi.org/10.1002/9781119188230.saseas0290

Odum, C.J., \& Oguamanam, C.C. (2020). Archaeotourism and archaeological heritage in Igboland, Nigeria. African Journal of Hospitality, Tourism and Leisure, 9(4), 639-654

Prentice, R.C., Witt, S.F., \& Hamer, C. (1998). Tourism as experience: The case of heritage parks. Annals of Tourism Research, 25(1), 1-24. http://dx.doi.org/10.1016/S0160-7383(98)00084-X

Rapidah, M.S., Mohamed, K.R., Ali, C.A., Leman, M.S., \& Saidin, M. (2018). A geotouristic itinerary: A proposal for geotourism and Archaeotourism development of Lenggong Valley, Perak, Malaysia. Geojournal of Tourism and Geosites, 22(2), 597-624. http://dx.doi.org/10.30892/gtg.22227-314

Rogerson, C.M., \& Rogerson, J.M. (2018). Africa’s tourism economy: Uneven progress and challenges. In T. Binns, K. Lynch \& E. Nel (eds.), The Routledge Handbook of African Development. Abingdon: Routledge, 545-560.

Ross, D., Saxena, G., Correia, F., \& Deutz, P. (2017). Archaeological tourism: A creative approach. Annals of Tourism Research, 67, 37-47. http://dx.doi.org/ 10.1016/j.annals.2017.08.001

Silberberg, T. (1995). Cultural tourism and business opportunities for museums and heritage sites. Tourism Management, 16(5), 361-365. http://dx.doi.org/10.1016/0261-5177(95)00039-Q

Sing'ambi, E., \& Lwoga, N.B. (2018). Heritage attachment and domestic tourists' visits to heritage sites. International Journal of Culture, Tourism and Hospitality, 12 (3), 310-326. http://dx.doi.org/10.1108/IJCTHR-09-2017-0091

Tao, C., Eagles, P.F., \& Smith, S.L. (2004). Profiling Taiwanese ecotourists using a self-definition approach. Journal of Sustainable Tourism, 12(2), 149-168. http://dx.doi.org/10.1080/09669580408667230

Timothy, D.J., \& Nyaupane, G.P. (2009). Introduction: Heritage tourism and the less-developed world. In D.J. Timothy \& G.P. Nyaupane, G.P. (Eds.). Cultural Heritage and Tourism in the Developing World: A Regional Perspective. New York: Routledge, 3 - 19.

Verkerk, V. (2017). The potential of Wonderboom Nature Reserve as an Archaeotourism destination. Unpublished Masters Dissertation, Univ. of Pretoria, South Africa.

Virto, N.R., Lopez, F.B., \& Madariaga, J.G. (2011). Identifying motivations of archaeological sites visitors. Cuadernos de Estudios Empresariales, $21,97-113$.

$\mathrm{Xu}$, J., \& Chan, S. (2016). A new nature-based tourism motivation model: Testing the moderating effects of the push motivation. Tourism Management Perspectives, 18, 107-110. http://dx.doi.org/10.1016/j.tmp.2016.01.001

Yun, D., Hennessey, S., Macdonald, R., \& MacEachern, M. (2008). Typology of cultural tourists: An island study. Paper for $3^{\text {rd }}$ International Small Island Cultures Conference, University of Prince Edward Island, Canada.

Zhao, S., Nyaupane, G.P., \& Andereck, K. (2016). Exploring the differences between tourists visiting heritage sites and those visiting cultural events: A cognitive perspective. Conference Paper, Travel and Tourism Research Association, Advancing Tourism Research Globally, 54.

*** United Republic of Tanzania [URT] (2019). The 2018 Tourism Statistical Bulletin., Dar es Salaam: Ministry of Natural Resources and Tourism, Tourism Division.

*** World Bank (2019). Africa's Pulse: An Analysis of Issues Shaping Africa's Economic Future. Washington DC: International Bank for Reconstruction and Development/The World Bank. 